\section{Responses of Soil Insects to Mixed and Contiguous Plantings of Resistant and Susceptible Sweetpotato Cultivars}

\author{
James M. Schalk', Alfred Jones ${ }^{2}$, and Philip D. Dukes ${ }^{3}$ \\ U.S. Vegetable Laboratory, Agricultural Research Service, U.S. \\ Department of Agriculture, Charleston, SC 29414
}

\author{
Kenneth P. Burnham ${ }^{4}$ \\ Colorado Cooperative Fisheries and Wildlife Research Unit 201 Wagar \\ Building, Colorado State University, Fort Collins, CO 80523
}

Additional index words. Ipomoea batatas, plant resistance, wireworms, flea beetles, grubs, cucumber beetles, Conoderus spp., Diabrotica spp., Systena spp., Chaetocnema confinis, Plectris aliena, Phyllophaga ephilda

\begin{abstract}
This study was designed to determine if the preference of soil insects for sweetpotato [Ipomoea batatas (L.) Lam.] cultivars is affected by the proximity of resistant or susceptible plant cultivars at various spacings. Comparisons were made for damage caused by wireworms (Conoderus spp.), Diabrotica spp., Systena spp., sweetpotato flea beetles (Chaetocnema confinis Crotch), and grubs (Plectris aliena Chapin; Phyllophaga ephilida Say) in previously reported resistant and susceptible cultivars. Field plots were planted with a resistant cultivar, a susceptible cultivar, or the two cultivars intermixed. Large roots exhibited more insect damage than medium and small roots. When plant spacing was increased, roots were larger and insect damage more severe. Mixed plantings of resistant and susceptible cultivars significantly reduced insect damage in the susceptible plants. Planting regime did not influence insect damage for the resistant cultivars.
\end{abstract}

Sweetpotato roots are often damaged by a group of soil insect larvae that includes wireworms (Conoderus falli Lane, $C$. vespertinus Fabricius), Diabrotica spp. (D. balteata LeConte, D. undecimpunctata howardi Barber), Systena spp. (S. blanda Melsheimer, $S$. elongata Fabricius, S. frontalis Fabricius), sweetpotato flea beetle, and grubs. Insecticides have been the first line of defense in reducing root damage by these pests, but since the removal of the persistent chlorinated hydrocarbons, control has been unreliable. Therefore, the need for resistant cultivars is becoming increasingly important for continued production. Six cultivars with multiple resistance to the above pests were developed by the U.S. Vegetable Laboratory, Charleston, S.C. (Dukes et al., 1987; Hamilton et al., 1985; Jones et al., 1983, 1985, 1987a, 1989), and their effectiveness in reducing injury has been demonstrated (Jones et al., 1987b; Thompson and Hurly, 1989). The primary objective of this study was to compare the injury caused by some of the above soil pests to resistant and susceptible sweetpotato cultivars, in mixed and contiguous plantings at several spacings.

Received for publication 21 Jan. 1992. Accepted for publication 13 May 1992. The cost of publishing this paper was defrayed in part by the payment of page charges. Under postal regulations, this paper therefore must be hereby marked $a d$ vertisement solely to indicate this fact.

'Research Entomologist.

${ }^{2}$ Research Geneticist.

${ }^{3}$ Research Plant Pathologist.

${ }^{4}$ Research Biometrician.
Because of the difficulty of separating roots of different cultivars at harvest, three cultivars were chosen with easily identifiable skin or flesh color. The two cultivars resistant to soil insects were 'Regal' and 'Sumor' (red skin with orange flesh and tan skin with white flesh, respectively). The susceptible entry chosen was SC-1149-19 (tan skin with orange flesh). Before inspecting the roots for insect injury, they were graded for size (small: 3 to $5 \mathrm{~cm}$ in diameter $\times 5$ to $18 \mathrm{~cm}$ long; medium: 5 to $9 \mathrm{~cm}$ in diameter $\times 8$ to 23 $\mathrm{cm}$ long; large: $>10 \mathrm{~cm}$ in diameter $\times 16$ to $30 \mathrm{~cm}$ long). Since root damage by wire-
"Percentage of roots damaged by Plectris aliena (50\%).

"Mean separation within columns by LSD, $P=0.05$. worms, Diabrotica spp., or Systena spp. is similar and difficult to separate at harvest, such injury was classified jointly as a complex termed WDS (Schalk et al., 1986). Root damage by that complex was rated for percent roots with damage (number of roots with injury divided by the total number of roots) and as a severity index obtained by assigning each root a rating based on the number of feeding scars $(0=$ no scars, $1=$ one to five scars, $2=$ six to 10 scars, $4=$ more than 10 scars) and averaging the rating scores. Sweetpotato flea beetle (SPFB) and grub damage were recorded as the percentage of roots injured (Jones et al., 1979).

Resistant ('Regal') and susceptible (SC1149-19) entries were planted on 3 May 1987. In 1988, two resistant entries ('Regal' and 'Sumor') and a susceptible entry (SC-114919) were planted on 3 June. In both years, each plot consisted of five rows $6.1 \mathrm{~m}$ long, spaced $91 \mathrm{~cm}$ apart. In 1987 the distance between plants was $30.5 \mathrm{~cm}$ within the row, and the five-row plots were spaced $6.1 \mathrm{~m}$ apart. In 1988, the five-row plots were separated within rows by $6.1 \mathrm{~m}$, between rows by $1.8 \mathrm{~m}$, and the uniform distance between plants within the rows was one of four spacings $(23,46,69$, and $91 \mathrm{~cm})$. Roots were harvested the first year on 10 Oct. and on 24 Oct. the 2 nd year.

In both years, the design was a randomized complete block (RCB) with five blocks (replicates). The nature and number of the treatments differed in the 2 years; however, in both years there was a moderately complex structure to the treatments in terms of cultivar mixes and plant spacings. There were four treatments in 1987, based on two cultivars, denoted S (susceptible, SC-1149-19) and R (resistant, 'Regal'); two treatments as pure plots of $\mathrm{S}$ and $\mathrm{R}$ and two treatments as mixed plots. Mixed plots in 1987 were alternating individual plants (ALT 1, ...SRSR...) and alternating sets of five plants (ALT 5, . . SSSSSRRRRR...). In 1988 there were 20 treatments with a two-factor treatment design structure where factor 1 was pure

\begin{tabular}{lcccc}
\hline \hline Root size & $\begin{array}{c}\text { WDS }^{\mathbf{z}} \\
\text { injured } \\
\text { roots (\%) }\end{array}$ & $\begin{array}{c}\text { WDS }^{y} \\
\text { severity } \\
\text { index }\end{array}$ & $\begin{array}{c}\text { SPFB }^{\mathbf{x}} \\
\text { injured } \\
\text { roots (\%) }\end{array}$ & $\begin{array}{c}\text { Grubsw }^{\mathrm{w}} \\
\text { injured } \\
\text { roots (\%) }\end{array}$ \\
\hline Large & & 1987 & & \\
Medium & $91.4 \mathrm{a}^{\mathrm{u}}$ & $2.1 \mathrm{a}$ & $28.3 \mathrm{a}$ & $14.9 \mathrm{a}$ \\
Small & $72.7 \mathrm{~b}$ & $1.4 \mathrm{~b}$ & $19.7 \mathrm{~b}$ & $7.5 \mathrm{~b}$ \\
LSD & $41.4 \mathrm{c}$ & $0.7 \mathrm{c}$ & $12.9 \mathrm{~b}$ & $7.5 \mathrm{~b}$ \\
& 4.7 & 0.2 & 7.5 & 7.1 \\
Large & & 1988 & & $7.7 \mathrm{a}$ \\
Medium & $75.1 \mathrm{a}$ & $1.9 \mathrm{a}$ & $27.4 \mathrm{a}$ & $3.9 \mathrm{~b}$ \\
Small & $51.4 \mathrm{~b}$ & $1.1 \mathrm{~b}$ & $17.1 \mathrm{~b}$ & $1.9 \mathrm{~b}$ \\
LSD & $28.9 \mathrm{c}$ & $0.5 \mathrm{c}$ & $8.3 \mathrm{c}$ & 2.8 \\
\hline
\end{tabular}

${ }^{2}$ Percentage of roots damaged by wireworms (Conoderus falli, C. vespertinus), Diabrotica (D. balteata, D. undecimpunctata howardi), Systena (S. blanda, S. frontalis, S. elongata).

'Wireworn, Diabrotica, Systena; severity index: $0=$ no scars, $1=$ one to five scars, $2=$ six to 10 scars, $4=$ more than 10 scars; averaged over all harvested roots.

'Percentage of roots damaged by sweetpotato flea beetle, Chaetocnema confinis.

"Medium, roots 5 to $9 \mathrm{~cm}$ in diameter $\times 8$ to $23 \mathrm{~cm}$ long; large, roots $>10 \mathrm{~cm}$ in diameter $\times 16$ to $30 \mathrm{~cm}$ long; small, roots 3 to $5 \mathrm{~cm}$ in diameter $\mathrm{x} 5$ to $18 \mathrm{~cm}$ long. 
Table 2. Mean injury rating for combined and pure stands of resistant ('Regal') and susceptible (SC1149-19) sweetpotato roots to soil insects in $1987 .{ }^{2}$

\begin{tabular}{|c|c|c|c|c|c|}
\hline Design & Plant & $\begin{array}{c}\text { WDS } \\
\text { injured } \\
\text { roots } \\
(\%) \\
\end{array}$ & $\begin{array}{l}\text { WDS } \\
\text { severity } \\
\text { index }\end{array}$ & $\begin{array}{c}\text { SPFBx } \\
\text { injured } \\
\text { roots } \\
(\%) \\
\end{array}$ & $\begin{array}{c}\text { Grubs" } \\
\text { injured } \\
\text { roots } \\
(\%) \\
\end{array}$ \\
\hline $\begin{array}{l}\text { Regal(1) }+ \\
\quad \text { Suscep(1)u }\end{array}$ & $\begin{array}{l}\text { Resistant } \\
\text { Susceptible }\end{array}$ & $\begin{array}{l}25.4 \mathrm{~b}^{4} \\
75.6 \mathrm{a}\end{array}$ & $\begin{array}{ll}0.3 & b \\
1.4 & a\end{array}$ & $\begin{array}{r}3.3 \mathrm{~b} \\
30.2 \mathrm{a}\end{array}$ & $\begin{array}{r}2.4 \\
15.2\end{array}$ \\
\hline $\begin{array}{l}\text { Regal(5) }+ \\
\quad \text { Suscep }(5)^{u} \\
\text { Regal (control)' } \\
\text { Suscep (control)t }\end{array}$ & $\begin{array}{l}\text { Resistant } \\
\text { Susceptible }\end{array}$ & $\begin{array}{l}30.9 \mathrm{~b} \\
80.8 \mathrm{a} \\
28.9 \mathrm{~b} \\
81.9 \mathrm{a}\end{array}$ & $\begin{array}{ll}0.4 & \mathrm{~b} \\
1.7 & \mathrm{a} \\
0.3 & \mathrm{~b} \\
1.7 & \mathrm{a}\end{array}$ & $\begin{array}{r}2.6 \mathrm{~b} \\
38.7 \mathrm{a} \\
3.5 \mathrm{~b} \\
30.1 \mathrm{a}\end{array}$ & $\begin{array}{r}2.8 \\
13.1 \\
9.7 \\
7.3\end{array}$ \\
\hline LSD & & 11.2 & 0.31 & 11.6 & 16.2 \\
\hline
\end{tabular}

${ }^{2}$ Percentage of roots damaged by wireworms (Conoderus falli, $C$. vespertinus), Diabrotica (D. balteata, D. undecimpunctata howardi), and Systena (S. blanda, S. frontalis, S. elongata).

'Wireworm, Diabrotica, Systena; See Table 1 for severity index ratings.

xPercentage of roots damaged by sweetpotato flea beetle.

wercentage of roots damaged by Plectris aliena.

'Mean separation within columns by LSD, $P=0.05$.

'Results are only for 'Regal' (resistant) or SC-1149-19 (susceptible) alternated (every other plant, or every fifth plant, spaced $30.5 \mathrm{~cm}$ apart).

'Pure stand.

Table 3. Mean injury rating for resistant ('Regal' or 'Sumor') and susceptible (SC-1149-19) sweetpotatoes to soil insects as influenced by contiguous and mixed alternate plantings (1988).

\begin{tabular}{|c|c|c|c|c|c|}
\hline Design & Plant & $\begin{array}{c}\text { WDS }^{z} \\
\text { injured } \\
\text { roots } \\
(\%)\end{array}$ & $\begin{array}{l}\text { WDS } \\
\text { index } \\
\text { roots }\end{array}$ & $\begin{array}{c}\text { SPFBx } \\
\text { injured } \\
\text { roots } \\
(\%)\end{array}$ & $\begin{array}{l}\text { Grubs } \\
\text { injured } \\
\text { roots } \\
(\%)\end{array}$ \\
\hline $\begin{array}{l}\text { Susceptible + } \\
\text { Sumor" } \\
\text { Susceptible + }\end{array}$ & Susceptible & $74.7 \mathrm{a}^{2}$ & $1.8 \mathrm{~b}$ & $31.6 \mathrm{~b}$ & $4.8 \mathrm{~b}$ \\
\hline & Susceptible & $69.2 \mathrm{~b}$ & $1.4 \mathrm{c}$ & $21.9 \mathrm{c}$ & $4.4 \mathrm{~b}$ \\
\hline $\begin{array}{l}\text { Susceptible' } \\
\text { Sumor }+\end{array}$ & Regal & $23.9 \mathrm{c}$ & $0.3 \mathrm{de}$ & $0.2 \mathrm{~d}$ & $0.6 \mathrm{c}$ \\
\hline $\begin{array}{l}\text { Susceptible }^{s} \\
\text { Susceptible (control) } \\
\text { Regal (control) } \\
\text { Sumor (control) } \\
\text { Sur }\end{array}$ & Sumor & $\begin{array}{l}12.3 \mathrm{~d} \\
79.5 \mathrm{a} \\
25.2 \mathrm{c} \\
14.3 \mathrm{~d}\end{array}$ & $\begin{array}{l}0.1 \mathrm{f} \\
2.0 \mathrm{a} \\
0.3 \mathrm{de} \\
0.2 \mathrm{ef}\end{array}$ & $\begin{array}{r}2.1 \mathrm{~d} \\
38.9 \mathrm{a} \\
0.5 \mathrm{~d} \\
2.4 \mathrm{~d}\end{array}$ & $\begin{array}{l}0.9 \mathrm{c} \\
8.5 \mathrm{a} \\
1.1 \mathrm{c} \\
1.1 \mathrm{c}\end{array}$ \\
\hline LSD & & 5.3 & 0.13 & 4.6 & 2.5 \\
\hline
\end{tabular}

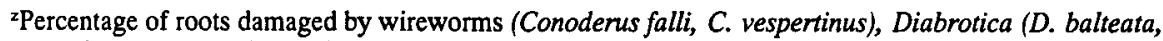
D. undecimpunctata howardi), and Systena (S. blanda, S. frontalis, S. elongata).

'See Table 1 for severity index.

xPercentage of roots damaged by sweetpotato flea beetle.

"Percentage of roots damaged by Plectris aliena $(50 \%)$.

vean separation within columns by LSD, $P=0.05$.

'Results are only for susceptible plants SC-1149-19 alternated with 'Sumor' or 'Regal'.

'Results are only for 'Regal' (resistant) alternated with the susceptible plants (SC-1149-19).

"Results are only for 'Sumor' (resistant) alternated with the susceptible (SC-1149-19).

'Pure stand.

vs. mixed plots and factor 2 was spacing between individual plants. Factor 1 was cultivar mix with five levels based on one susceptible (S, SC-1149-19) and two resistant cultivars (R1, 'Regal' and R2, 'Sumor'). The mixed S-R plots alternated individual plants. Thus, factor one treatment levels (five levels) were: . ...SSSSS ..., ...R1 R1 R1 R1 R1..., ...R2 R2 R2 R2 R2..., ...SR1 SR1 SR1 SR1 SRI..., and ...SR2 SR2 SR2 SR2 SR2 ... Factor 2 was the spacing of individual plants at the four distances noted, where the distance between plants was uniform for one of the four spacings. The 20 treatments used were all possible combinations of these five and four levels. Correlations were determined for the 1988 data relative to plant spacing and root size.

Standard analysis of variance (ANOVA) methods were used to analyze whole-plot response variables such as number of roots and overall measures of damage. Root size within plots was analyzed as a split-plot factor in conjunction with the RCB ANOVA applied to whole plots. For data from 1988, a standard factorial ANOVA for RCB design was used for some initial analysis. For data from both years, mean separation tests (least significant difference) were used, and for the 1988 data, contrasts (linear, quadratic, and cubic) were used on the plant spacing treatment factor. Reporting only results of such standard analysis is not sufficient here; rather, separate results are needed by cultivar even in the mixed planting case, wherein cultivar becomes a split-plot factor (but only for mixed plots). A nonstandard analysis would be needed, unless there was no within-plot cor- relation between cultivar types in the mixed plots. Based on a variety of analyses, it was our judgment that this zero correlation assumption was safe. Therefore, standard ANOVA was used for the results reported here, even by cultivar in the mixed plots.

Root injury was related to size, since damage was greater on the larger than on the smaller roots for all insect catergories (Table 1), which confirmed previous suggestions (Cuthbert and Jones, 1972).

In 1987, WDS injury, severity index (WDS), and SPFB injury to resistant and susceptible cultivars remained consistent with respect to plant entry regardless of treatment (Table 2). No differences were found for grub damage.

In 1988, the influence of the mixed susceptible and resistant plant entries generally provided lower levels of damage for SC-114919 for all insects, while the highest insect damage occurred with the contiguous planting of SC-1149-19. The contiguous and mixed plantings of 'Sumor' (with or without SC1149-19) and 'Regal' (with or without SC1149-19) exhibited high resistance levels to all insects (Table 3).

Increased plant spacing was positively correlated with development of larger roots $(r=0.514 ; P=0.01)$. There also was an increase in root damage by the WDS complex and grubs, presumably because of the increase in root size (Table 4).

Since the damage reduction in the mixed plantings (resistant plus susceptible) was generally consistent for all catergories (WDS, SPFB, grubs) in 1988, the results should not be considered an aberration. One explanation for that to occur in one season and not another may be related to variation in abundance of causal insect species as well as life stages of individual species affecting injury levels. Researchers have demonstrated the allelopathic effects of peridermal extracts of 'Regal' on weed growth and seed germination (Harrison and Peterson, 1986; Peterson and Harrison, 1991). These peridermal compounds may have similar effects on soil insect behavior by altering the environment so that a degree of protection for the susceptible cultivar was realized. The protection may be of the nonpreference type due to larval movement away from 'Regal', possibly in response to peridermal resistance factors (Chalfant et al., 1990; Schalk et al., 1986a, 1986b). Planting regime did not influence insect damage to the resistant cultivars in either year, thus providing control of insect damage without the use of insecticides. This research demonstrates that insect behavior, as indicated by root damage to a susceptible plant, can be altered by the addition of genetically resistant cultivars to the edaphic environment.

\section{Literature Cited}

Chalfant, R.B., R.K. Janson, D.R. Seal, and J.M Schalk. 1990. Ecology and management of sweetpotato insects. Annu. Rev.Entomol. $35: 157-180$

Cuthbert, F.P., Jr., and A. Jones. 1972. Resistance in sweetpotatoes to Coleoptera increased 
Table 4. Mean reaction of all sweetpotato plant entries to soil insect injury as influenced by plant spacing in 1988; also shown are the observed significance levels of ( $P$ values) linear, quadratic, and cubic contrasts on plant spacing.

\begin{tabular}{|c|c|c|c|c|}
\hline $\begin{array}{l}\text { Plant } \\
\text { spacing } \\
\text { (cm) }\end{array}$ & $\begin{array}{l}\text { WDS }^{\mathbf{2}} \\
\text { injured } \\
\text { roots } \\
(\%)\end{array}$ & $\begin{array}{l}\text { WDS } \\
\text { severity } \\
\text { index }\end{array}$ & $\begin{array}{c}\text { SPFBx } \\
\text { injured } \\
\text { roots } \\
(\%)\end{array}$ & $\begin{array}{l}\text { Grubs } \\
\text { injured } \\
\text { roots } \\
(\%)\end{array}$ \\
\hline $\begin{array}{l}22.9 \\
45.7 \\
68.6 \\
91.4\end{array}$ & $\begin{array}{l}39.9 \\
40.7 \\
43.9 \\
46.3\end{array}$ & $\begin{array}{l}0.7 \\
0.8 \\
0.9 \\
1.0\end{array}$ & $\begin{array}{l}12.9 \\
12.6 \\
14.9 \\
15.4\end{array}$ & $\begin{array}{l}2.0 \\
3.7 \\
4.0 \\
2.5\end{array}$ \\
\hline $\begin{array}{l}\text { Significance } \\
\text { Linear } \\
\text { Quadratic } \\
\text { Cubic }\end{array}$ & $\begin{array}{l}0.0007 \\
0.5674 \\
0.5974\end{array}$ & $\begin{array}{l}0.0001 \\
0.8924 \\
0.8590\end{array}$ & $\begin{array}{l}0.0833 \\
0.7971 \\
0.4265\end{array}$ & $\begin{array}{l}0.5616 \\
0.0165 \\
0.8934\end{array}$ \\
\hline
\end{tabular}

Percentage of roots damaged by wireworms (Conoderus falli, C. vespertinus), Diabrotica (D. balteata, D. undecimpunctata howardi), Systena (S. blanda, S. frontalis, S. elongata).

See Table 1 for severity index.

${ }^{x}$ Percentage of roots damaged by sweetpotato flea beetle.

"Percentage of roots damaged by Plectris aliena.

by recurrent selection. J. Econ. Entomol. 65:1655-1658.

Dukes, P.D., M.G. Hamilton, A. Jones, and J.M. Schalk. 1987. 'Sumor' A multi-use sweetpotato. HortScience 22:170-171.

Hamilton, M.G., P.D. Dukes, A. Jones, and J.M. Schalk. 1985. 'HighDry' sweetpotato. HortScience 20:954-955.

Harrison, H.F., Jr., and J.K. Peterson. 1986. Allelopathic effects of sweetpotato (Ipomoea ba- tatas) on yellow nutsedge (Cyperus esculentus) and alfalfa (Medicago sativa). Weed Sci. 34:623 627 .

Jones, A., J.M. Schalk, and P.D. Dukes. 1979 Heritability estimates for resistance in sweet potato to soil insects. J. Amer. Soc Hort. Sci. 104:424-426.

Jones, A., P. D. Dukes, J.M. Schalk, M.G. Hamilton, M.A. Mullen, R.A. Baumgardner, D.R Paterson, and T.E. Boswell. 1983. 'Resisto' sweetpotato. HortScience 18:251-252.

Jones, A., P.D. Dukes, J.M. Schalk, M.G. Hamilton, M.A. Mullen, R.A. Paterson, and T.E. Boswell. 1985. 'Regal' sweetpotato. HortScience 20:781-782.

Jones, A., P.D. Dukes, J.M. Schalk, M.G. Hamilton, and R.A. Baumgardner. 1987a. 'Southem Delite' sweetpotato. HortScience 22:329330 .

Jones, A., J.M. Schalk, and P. D. Dukes. 1987b. Control of soil insect injury by resistance in sweetpotato. J. Amer. Soc. Hort. Sci. 112:195197.

Jones, A., P.D. Dukes, J.M. Schalk, and M.G. Hamilton, 1989. 'Excel' sweetpotato. HortScience. 24:171-172.

Peterson, J.P. and H.F. Harrison. 1991. Differential inhibition of seed germination by extracts of sweetpotato, lpomoea batatas, root periderm. Weed Sci. 39:119-123.

Schalk, J.M., A. Jones, and P.D. Dukes. 1986a. Factors associated with resistance in recently developed sweetpotato cultivars and germplasm to the banded cucumber beetle, Diabrotica balteata LeConte. J. Agr. Entomol. 3:329-334.

Schalk, J.M., A. Jones, and P. D. Dukes. 1986b. The anatomy of sweet potato periderm and its relationship to wireworm, Diabrotica systena resistance. J. Agr. Entomol. 3:350--356.

Thompson, P.G. and R.M. Hurly. 1989. Marketable yields of insect-resistant sweetpotato cultivars. Miss. Agr. For. Expt. Sta. Bul. 14:1-3. 